\title{
First record of the marine turtle leech (Ozobranchus margoi) on hawksbill turtles (Eretmochelys imbricata) in the inner granitic Seychelles
}

\begin{tabular}{|c|c|}
\hline \multicolumn{2}{|c|}{$\begin{array}{l}\text { Authors: } \\
\text { Byron M. Göpper }{ }^{1} \\
\text { Nina M. Voogt }^{1} \\
\text { Andre Ganswindt }^{1,2}\end{array}$} \\
\hline \multicolumn{2}{|c|}{$\begin{array}{l}\text { Affiliations: } \\
{ }^{1} \text { Department of Anatomy } \\
\text { and Physiology, University } \\
\text { of Pretoria, South Africa }\end{array}$} \\
\hline \multicolumn{2}{|c|}{$\begin{array}{l}{ }^{2} \text { Mammal Research Institute, } \\
\text { Department of Zoology } \\
\text { and Entomology, University } \\
\text { of Pretoria, South Africa }\end{array}$} \\
\hline \multicolumn{2}{|c|}{$\begin{array}{l}\text { Corresponding author: } \\
\text { Andre Ganswindt, } \\
\text { andre.ganswindt@up.ac.za }\end{array}$} \\
\hline \multicolumn{2}{|c|}{$\begin{array}{l}\text { Dates: } \\
\text { Received: } 22 \text { Dec. } 2017 \\
\text { Accepted: } 24 \text { July } 2018 \\
\text { Published: } 30 \text { Aug. } 2018\end{array}$} \\
\hline \multicolumn{2}{|c|}{$\begin{array}{l}\text { How to cite this article: } \\
\text { Göpper, B.M., Voogt, N.M. \& } \\
\text { Ganswindt, A., 2018, 'First } \\
\text { record of the marine turtle } \\
\text { leech (Ozobranchus margoi) } \\
\text { on hawksbill turtles } \\
\text { (Eretmochelys imbricata) in } \\
\text { the inner granitic Seychelles', } \\
\text { Onderstepoort Journal of } \\
\text { Veterinary Research } 85(1) \text {, } \\
\text { a1604. https://doi.org/ } \\
\text { 10.4102/ojvr.v85i1.1604 }\end{array}$} \\
\hline \multicolumn{2}{|c|}{$\begin{array}{l}\text { Copyright: } \\
\text { (C) 2018. The Authors. } \\
\text { Licensee: AOSIS. This work } \\
\text { is licensed under the } \\
\text { Creative Commons } \\
\text { Attribution License. }\end{array}$} \\
\hline \multicolumn{2}{|l|}{ Read online: } \\
\hline 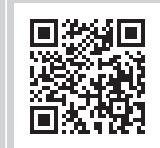 & $\begin{array}{l}\text { Scan this QR } \\
\text { code with your } \\
\text { smart phone or } \\
\text { mobile device } \\
\text { to read online. }\end{array}$ \\
\hline
\end{tabular}

Ozobranchus spp. are leeches that feed solely on turtle blood. They are common ectoparasites found on a range of marine turtle species, with some species of the leech being implicated as vectors of fibropapilloma-associated turtle herpesvirus (FPTHV). Green (Chelonia mydas) and hawksbill (Eretmochelys imbricata) turtles are the two commonly occurring species in the inner granitic islands of the Seychelles. Routine monitoring of nesting turtles on Cousine Island, Seychelles, allowed for opportunistic sightings of leeches on two hawksbill females. In both cases infestation was low, with three leeches collected off one female turtle and five off the other. No obvious signs of papillomas secondary to infection of FPTHV were seen. All of the turtle leeches collected were determined to be Ozobranchus margoi as they had five pairs of lateral digiform branchiae. The specimens were deposited in the Seychelles Natural History Museum on Mahé. To the best of our knowledge this is the first record of Ozobranchus margoi recorded in the inner granitic Seychelles on hawksbill turtles.

\section{Introduction}

The genus Ozobranchus is characterised, among other features, by their anterior abdominal somites that each possess a pair of gills that are divided distally into many branchiae (Richardson 1969). They are the only non-piscicolid marine leeches to be permanent parasites of sea turtles and attach onto the turtle's skin, particularly around the cloaca, head region and flippers (Sawyer 1986). Ozobranchs are stationary leeches, remaining on their host for their entire life cycle. Numerous cocoons are deposited on the turtle's plastron where they hatch. Newly hatched leeches feed on the same host as their parents. This cycle is repeated, ultimately leading to large numbers of leeches on an individual (Sawyer 1986). Owing to the difficulties of studying their sea turtle hosts, very little is known about sea turtle leeches and whether they are able to survive partly without a host or utilise an alternate host (McGowin et al. 2011). However, more knowledge about the life cycle of sea turtle leeches would be beneficial, as some species of Ozobranchus have been implicated as mechanical vectors of fibropapillomaassociated turtle herpesvirus (FPTHV), a neoplastic disease causing epithelial tumours in sea turtles (Greenblatt et al. 2004).

Ozobranchus margoi parasitise several species of sea turtle, namely green turtles (Chelonia mydas; Richardson 1969), Kemp's ridley turtles (Lepidochelys kempii; Davies \& Chapman 1974), hawksbill turtles (Eretmochelys imbricata; Bunkley-Williams et al. 2008), as well as loggerhead turtles (Caretta caretta; Insacco, Violani \& Zava 2000). However, O. margoi show some degree of host preference and are most frequently associated with loggerhead turtles (Bunkley-Williams et al. 2008).

Geographically there have been reports of O. margoi from Florida (Davies 1978; Davies \& Chapman 1974; McGowin et al. 2011; Sawyer, Lawler \& Oversrteet 1975; Truong 2014; Truong \& McGowin 2011), North Carolina (Schwartz 1974), Hawaii (Balazs 1980), Barbados (Truong 2014), Brazil (Peralta et al. 2003; Rodenbusch et al. 2012; Truong 2014), Puerto Rico (BunkleyWilliams et al. 2008), Uruguay (Cordero 1929), Adriatic Sea (Piccolo \& Manfredi 2003; Scaravelli, Affronte \& Costa 2003), Italy (Apathy 1890), Mediterranean sea (Insacco et al. 2000), Tunisia (Karaa et al. 2011), South Africa (Hughes, Bass \& Mentis 1967), India (Sanjeeva Raj 1959), Japan (Oka 1927), Taiwan (Cheng-Tsung \& I-Jiunn 2013; Tseng, Leu \& Cheng 2017) and Australia (Loop, Miller \& Limpus 1995; Richardson 1969). However, there are no published reports documenting the occurrence of O. margoi on turtles in the inner granitic Seychelles. To the best of the authors' knowledge, this is the first recorded report of O. margoi parasitising E. imbricata in the Seychelles Archipelago. 


\section{Material and methods}

Observations were made on Cousine Island $\left(-4.350577^{\circ} \mathrm{S}\right.$, $\left.55.647527^{\circ} \mathrm{E}\right)$, a 25 -hectare island with a $1-\mathrm{km}$ stretch of beach. The island is situated in the inner granitic Seychelles, Seychelles Archipelago, Indian Ocean. Within the inner granitic islands, Cousine Island is an important nesting beach for hawksbill turtles (E. imbricata). The islands' conservation and turtle monitoring programme has been running since 1991 (Hitchins et al. 1999). While following Cousine Island's standard routine monitoring protocols set out for nesting female hawksbill turtles, leeches were randomly spotted and opportunistically collected from two separate nesting female hawksbill turtles that came up to nest on Cousine Island's beach during the 2015-2016 season. Collection of specimens took place on 12 January 2016 and 22 January 2016.

\section{Results}

All leeches were located attached to the soft tissue around the cloaca of both female turtles (Figure 1). A total of eight leeches were collected, three off the female turtle with flipper tags SCA 3814 (left) and SCA 3815 (right), and five off the female turtle with flipper tags SCA 7048 (left) and SCA 7668 (right). Five specimens were preserved in $70 \%$ ethanol and the remaining three in $10 \%$ formalin. Subsequently, three of the specimens were deposited at the Natural History Museum, Mahé, Seychelles, for further studies and to make them available to other researchers. Therefore, the specimens' corresponding voucher numbers are: 1443/16 (collection date: 12 January 2016) preserved in 70\% ethanol, 1444/16 (collection date: 22 January 2016) preserved in 70\% ethanol and 1445/16 (collection date: 22 January 2016) preserved in $10 \%$ formalin.

The bodies of all eight specimens showed a distinguishable trachelosome and urosome, with a posterior sucker clearly visible. Furthermore, five pairs of gills were visible on the urosome (Figure 2). Based on these characteristics, the leeches were identified as Ozobranchus margoi (Davies 1978).

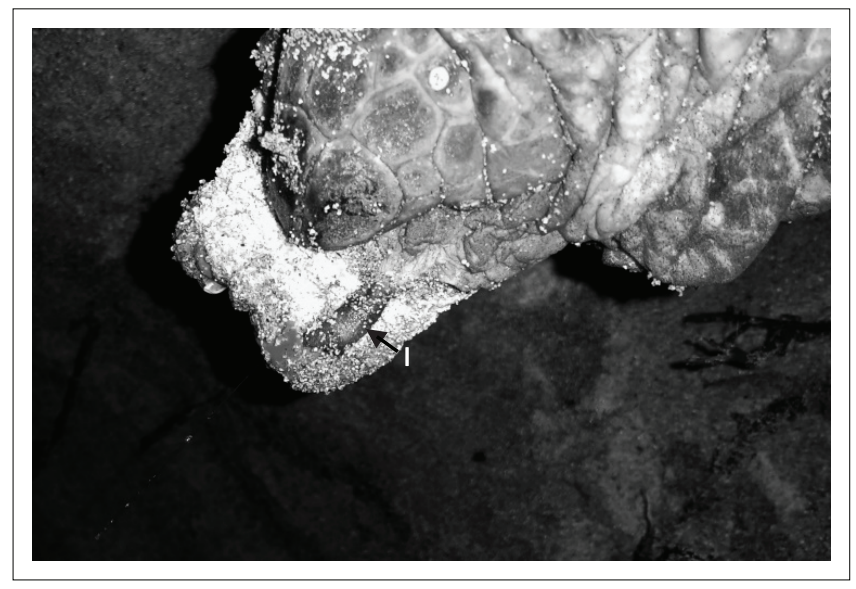

I, leech.

FIGURE 1: Ozobranchus margoi observed on nesting hawksbill turtle. Photo taken of tail and cloaca while eggs were being laid.

\section{Discussion}

Based on a literature search for published cases of O. margoi using various keyword combination searches in Google Scholar and the database on the Sea Turtle Network (http:/ / www.seaturtle.org/library/) no records of O. margoi parasitising E. imbricata in the Seychelles could be found. Samways et al. (2010), the main reference text for Cousine Island's fauna, flora and ecology, also revealed no records; therefore, to the best of the authors' knowledge, this is the first record of $O$. margoi parasitising on hawksbill turtles in the inner granitic Seychelles.

Green and hawksbill turtles are the two commonly occurring species in the inner granitic islands of the Seychelles. Future standard operating procedures for monitoring protocols of nesting female turtles are encouraged to include the recording of any observations of leeches or fibropapillomas. No obvious signs of papillomas were seen on the turtles in this study and in both cases infestation of leeches was low. As leeches are common on green turtles in other regions of the world, it would be interesting to further investigate the occurrence of Ozobranchus spp. in the Seychelles sea turtle populations, especially to see if other species (e.g. O. branchiatus) are also present.

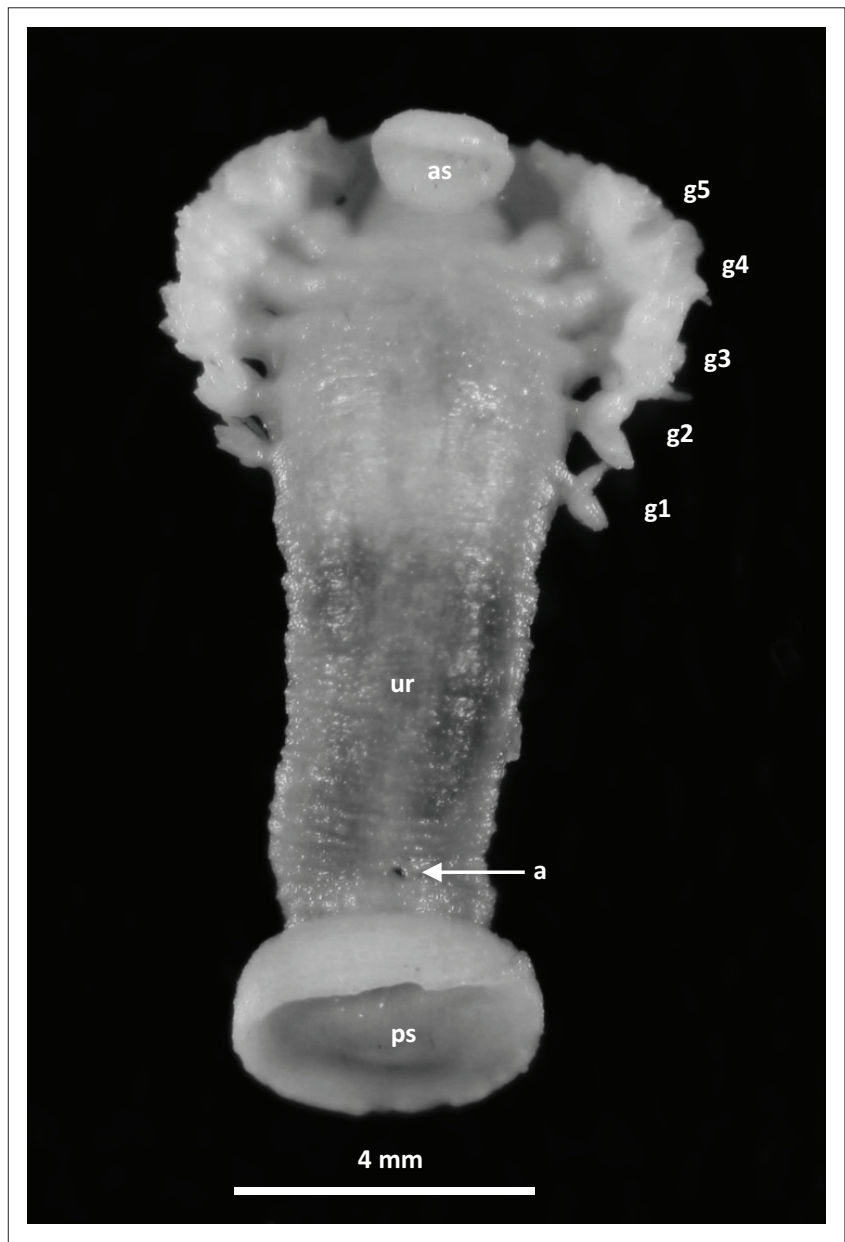

a, anus; as, anterior sucker; ps, posterior sucker; ur, urosome; g1-g5, gill set 1 to 5 . FIGURE 2: Ozobranchus margoi specimen. 


\section{Acknowledgements Competing interests}

The authors declare that they have no financial or personal relationships that may have inappropriately influenced them in writing this paper.

\section{Authors' contributions}

B.M.G. and N.M.V. collected the samples, submitted them to the Seychelles Natural History Museum and wrote the manuscript. A.G. made conceptual contributions and revisions to the manuscript. All authors contributed to editing the manuscript to its final form in preparation for publication.

\section{References}

Apathy, S.T., 1890, 'Pseudobranchellion margoi (Nova familia Hirudinearum)', OrvosTermeszettudomanyi Eresito 15, 122-127.

Balazs, G.H., 1980, 'Synopsis of biological data on the green turtle in the Hawail Islands', National Oceanographic and Atmospheric Administration Technical Memorandum 7, 141.

Bunkley-Williams, L., Williams Jr., E.H., Horrocks, J.A., Horta, H.C., Mignucci-Giannoni, A.A. \& Poponi, A.C., 2008, 'New leeches and diseases for the hawksbill sea turtle and the West Indies', Comparative Parasitology 75, 263-270. https://doi. org/10.1654/4252.1

Cheng-Tsung, T. \& I-Jiunn, C., 2013, 'Two new records of marine ozobranchid leeches (Oligochaete: Ozobranchidae) in Taiwan', Comparative Parasitology 80, 105-109. (Oligochaete: Ozobranchidae) in
https://doi.org/10.1654/4556.1

Cordero, E.H., 1929, 'Notes sur les hirudine'es. I. quelques observations sur la morphologie externe d'Ozobranchus margoi (Apathy)', Annales de Parasitologie 7, 209-217. https://doi.org/10.1051/parasite/1929073209

Davies, R.W., 1978, 'The morphology of Ozobranchus margoi (Apathy) (Hirudinoidea): A parasite of marine turtles', The Journal of Parasitology 64, 1092-1096. https:// doi.org $/ 10.2307 / 3279733$

Davies, R.W. \& Chapman, C.G., 1974, 'First record from North America of the piscicolid leech, Ozobranchus margoi, a parasite of marine turtles', Journal of the Fisheries Board of Canada 31, 104-106. https://doi.org/10.1139/f74-016

Greenblatt, R.J., Work, T.M., Balazs, G.H., Sutton, C.A., Casey, R.N. \& Casey, J.W., 2004 'The Ozobranchus leech is a candidate mechanical vector for the fibropapillomaassociated turtle herpesvirus found latently infecting skin tumors on Hawaiian green turtles (Chelonia mydas)', Virology 321, 101-110. https://doi.org/10.1016/j. virol.2003.12.026

Hitchins, P.M., Bourquin, O., Hitchins, S. \& Piper, S.E., 2004, 'Biometric data on hawksbill turtles (Eretmochelys imbricata) nesting at Cousine Island, Seychelles', Journal of Zoology 264, 371-381. https://doi.org/10.1017/S0952836904005850

Hughes, G.R., Bass, A.J. \& Mentis, M.T., 1967, 'Further studies on turtles in Tongaland, 1', Lammergeyer 7, 1-55.

Insacco, G., Violani, C. \& Zava, B., 2000, 'New records of Ozobranchus margoi (Apathy, 1890) on Caretta caretta (Linnaeus, 1758) for the Mediterranean sea', Actas del 3rd Congresso Nazionale Societas Herpetologica Italica 13, 167-168.
Karaa, S., Jribi, I., Bouain, A. \& Bradai, M.N., 2011, 'Preliminary study on parasites in Loggerhead (Caretta caretta) turtles from the southern Tunisian waters', in F. Bentivegna, F. Maffucci \& V. Mauriello (compilers), Book of Abstracts. 4th Mediterranean Conference of Marine Turtles Napoli, Italy, November 11-13, 2011, p. 120.

Loop, K.A., Miller, J.D. \& Limpus, C.J., 1995, 'Nesting by the hawksbill turtle (Eretmochelys imbricata) on Milman Island, Great Barrier Reef, Australia', Wildlife Research 22, 241-251. https://doi.org/10.1071/WR9950241

McGowin, A.E., Truong, T.M., Corbett, A.M., Bagley, D.A., Ehrhart, L.M., Bresette, M.J. et al., 2011, 'Genetic barcoding of marine leeches (Ozobranchus spp.) from Florida sea turtles and their divergence in host specificity', Molecular Ecology Resources 11, 271-278. https://doi.org/10.1111/j.1755-0998.2010.02946.x

Oka, A., 1927, 'Sur la Présence de l'Ozobranchus margoi au Japon, et description de cette Hirudinée', Proceedings of the Imperial Academy 3, 470-473.

Peralta, A.S.L., Werneck, M.R., Matos, E. \& Becker, J.H., 2003, 'Ocorrência do parasitismo em Chelonia mydas e Caretta caretta (Testudines, Cheloniidae) por Ozobranchus branchiatus e O. margoi (Hirudinea, Ozobranchidae) no litoral norte de São Paulo', Proceedings of the 30th Brazilian Congress of Veterinary Medicine.

Piccolo, G. \& Manfredi, M.T., 2003, 'New reports on parasites of marine turtles stranded along the Italian coasts', in D. Margaritoulis \& A. Demetropoulos (eds.), Proceedings of the First Mediterranean conference on marine turtles, Rome, Proceedings of the First Mediterranean conference on marine turtles, Rome,
October 24-28, 2001, pp. 207-211, Barcelona convention - Bern convention October 24-28, 2001, pp. 207-211
Bonn convention (CMS), Nicosia.

Richardson, L.R., 1969, 'The family Ozobranchidae redefined, and a novel Ozobranchiform leech from Murray River turtles (class Hirudinoidea: Order Rhynchobdelliformes)', Proceedings of the Linnean Society of New South Wales $94,62-80$.

Rodenbusch, C.R., Marks, F.S., Canal, C.W. \& Reck, J., 2012, 'Marine leech Ozobranchus margoi parasitizing Loggerhead turtle (Caretta caretta) in Rio Grande do Sul, Brazil', Revista Brasileira de Parasitologia Veterinária 21, 301-303. https://doi. org/10.1590/S1984-29612012000300023

Samways, M.P., Hitchins, P., Bourquin, O. \& Henwood, J., 2010, Tropical island recovery: Cousine island, Seychelles, Wiley-Blackwell, Chichester.

Sanjeeva Raj, P.S., 1959, 'Occurrence of Ozobranchus margoi Apathy (Hirudinea: Annelida) in the Indian seas', Current Science 28, 496-496.

Sawyer, R.T., 1986, Leech biology and behaviour, Clarendon Press, Oxford.

Sawyer, R.T., Lawler, A.R. \& Overstreet, R.M., 1975, 'Marine leeches of the eastern United States and the Gulf of Mexico with a key to the species', Journal of Natural History 9, 633-667. https://doi.org/10.1080/00222937500770531

Scaravelli, D., Affronte, M. \& Costa, F., 2003, 'Analysis of epibiont presence on Caretta caretta from Adriatic sea', in D. Margaritoulis \& A. Demetropoulos (eds.) Proceedings of the First Mediterranean conference on marine turtles, Rome, October 24-28, 2001, pp. 211-225, Barcelona Convention - Bern Convention Bonn Convention (CMS), Nicosia.

Schwartz, F.J., 1974, 'The marine leech Ozobranchus margoi (Hirudinea)', Journal of Parasitology 60, 889-890. https://doi.org/10.2307/3278927

Truong, T.M., 2014, 'Investigating DNA barcoding potentials and genetic structure in Ozobranchus spp. from Atlantic and Pacific Ocean sea turtles', MSc dissertation, Wright State University, USA.

Truong, T.M. \& McGowin, A.E., 2011, 'DNA barcoding of sea turtle leeches (Ozobranchus spp.) in Florida coastal waters', Abstracts of the 75th Anniversary Meeting of the Florida Academy of Sciences, Florida Institute of Technology, Melbourne, FL, p. 56.

Tseng, C.T., Leu, J.H. \& Cheng, I.J., 2017, 'On the genetic diversity of two species of the genus Ozobranchus (Hirudinida; Ozobranchidae) from the Atlantic and Pacific Oceans', Journal of the Marine Biological Association of the United Kingdom 98, 955-960. https://doi.org/10.1017/S0025315416001958 